\title{
Biocompatible water softening system using cationic protein from moringa oleifera extract
}

\author{
R. R. Nisha ${ }^{1}$ P. Jegathambal ${ }^{1} \cdot$ K. Parameswari ${ }^{2} \cdot$ K. Kirupa ${ }^{2}$
}

Received: 27 July 2015/Accepted: 12 July 2017 / Published online: 22 July 2017

(c) The Author(s) 2017. This article is an open access publication

\begin{abstract}
In developing countries like India, the deciding factors for the selection of the specific water purification system are the flow rate, cost of implementation and maintenance, availability of materials for fabrication or assembling, technical manpower, energy requirement and reliability. But most of them are energy and cost intensive which necessitate the development of cost-effective water purification system. In this study, the feasibility of development of an efficient and cost-effective water purifier using Moringa oleifera cationic protein coated sand column to treat drinking water is presented. Moringa oleifera seeds contain cationic antimicrobial protein which acts as biocoagulant in the removal of turbidity and also aids in water softening. The main disadvantage of using Moringa seeds in water purification is that the dissolved organic matter (DOM) which is left over in the water contributes to growth of any pathogens that come into contact with the stored water. To overcome this limitation, the Moringa oleifera cationic protein coated sand (MOCP c-sand) is prepared in which the flocculant and antimicrobial properties of the MOCP are maintained and the DOM to be rinsed away. The efficiency of MOCP c-sand in removing suspended particles and reducing total hardness (TH), chloride, total dissolved solids (TDS), electrical conductivity (EC) was also studied. Also, it is shown that the functionalized sand showed the same treatment efficiency even after being stored dry and in dehydrated condition for
\end{abstract}

P. Jegathambal

esther.jegatha2011@gmail.com

1 Water Institute, Karunya University, Karunya Nagar, Coimbatore 641114, India

2 Department of Chemistry, Karunya University, Karunya Nagar, Coimbatore 641114, India
3 months. This confirms MOCP c-sand's potential as a locally sustainable water treatment option for developing countries since other chemicals used in water purification are expensive.

Keywords Moringa oleifera cation protein - Water purification $\cdot c$-Sand $\cdot$ XRD $\cdot$ Column $\cdot$ SEM

\section{Introduction}

Existing methods of water purification are very diverse and are based on processes such as reverse osmosis, ion exchange, adsorption, ultra-filtration, distillation and photo-oxidation. The majority of them, however, have limitations, mainly high energy consumption and low efficiency. So it is necessary to develop a water purification system using locally available raw materials in the rural and peri-urban areas. In most of the conventional water treatment methods, alum and polyaluminum chloride are used for turbidity removal. The ion exchange is widely used for the removal of permanent hardness of water. These methods are not cost-effective, and in addition to that, the usage of aluminum in treatment units induces Alzheimer's disease (Ndabigengesere et al. 1995; Muyibi 1998; Crapper et al. 1973; Suet and Wing 1992). Research on natural coagulants has shown that Moringa oleifera seed is a natural coagulant aids in hardness, turbidity (50-90\%) and bacteria removal (Vijay et al. 2012; Yarahmadi et al. 2009; Sotheeswaran et al. 2011; Nwaiwu and Moses 2010; Mustapha 2013; Eman et al. 2010; Egbuikwem and Sangodoyin 2013; Mangale et al. 2012; Olayemi 1994; Dalen et al. 2009). The seeds are proven to be good in the removal of chemical oxygen demand (COD) also (Emelie et al. 2008). Moringa is a tropical tree which naturally 
grows in India, Africa, Central and South America (Malusare and Milind 2011; Fahey 2005; Anjorin et al. 2010; Vinoth et al. 2012). It contains chemical constituents such as alkaloids, tannins, flavonoids, carbohydrates, amino acids, fatty acid glycosides (Nilani et al. 2012; Stavros and John 2002). Also it was proved that Moringa oleifera together with sand filtration exhibited an improvement in drinking water in developing countries by removing $97 \%$ turbidity and $89 \%$ Escherichia coli (E. coli). Though this method of clarifying is being followed since the twentieth century (Mumuni et al. 2013), the limitations remain in controlled dosage based on $\mathrm{pH}$, water quality and skilled labors for preparation of natural coagulants from plant seeds and nuts. The main drawback of this method is that the water treated in this method will have the presence of dissolved organic matter which contributes to the regrowth of pathogens and prevents the clarified water from being potable after some time (Mcullough 2012). So, the water which is clarified using this method cannot be stored. Though many studies were carried out on Moringa oleifera in the removal of turbidity and biological contaminant, the effects of storage condition on its performance are to be explored further (Muyibi et al. 2004).

Moringa oleifera seeds are used as a primary coagulant in drinking water clarification due to the presence of cationic coagulant protein which is able to reduce turbidity of treated water (Mcullough 2012). The seeds also act as an antimicrobial agent against many microorganism (Alo et al. 2012). Seeds are powdered and directly added to the water. The seed kernels contain significant quantities of series of water-soluble protein which carry positive charge to solution. When this protein gets added to raw water, it binds with the predominantly negatively charged contaminants which makes the raw water turbid. Under proper agitation these bound particulates then grow in size to form the flocs, which may be left to settle by gravity or removed by sedimentation.

In this study, preparation of coated sand (c-sand) with Moringa oleifera cationic protein (MOCP) through adsorption of the MOCP to the surface of sand was done to increase the storage time. This allows the flocculants and antimicrobial properties of the MOCP to be maintained and the excess DOM to be rinsed away. The prepared sand at different quantities of MOCP was tested for the removal of hardness, chloride, TDS, turbidity and coliforms in water. The characterization study was also carried out to understand the process of water purification using c-sand.

\section{Materials and methods}

\section{MOCP coated sand preparation}

The Moringa extract was obtained by adding Moringa dry seed powder in $100 \mathrm{ml}$ of water and stirring it for $30 \mathrm{~min}$ using a magnetic stirrer. The extract thus obtained was allowed to pass through Whatman filter paper (Grade 41) to remove suspended matter. The extract obtained was allowed to pass through sand of uniform size of grain size $4 \mathrm{~mm}$ and allowed to get saturated. The sand particles are allowed to get in contact with extract for $24 \mathrm{~h}$. During this time, the cationic protein in the extract gets adhered to the surface of the sand particles. The prepared sand particles (c-sand) are allowed to get dried at room temperature overnight. The sand of Conc. 2 was made by adding $2 \mathrm{~g}$ of Moringa dry seed powder in $100 \mathrm{ml}$ of water and stirring it and extracting its extract by following the above procedure, then adding the extract in $300 \mathrm{~g}$ of sand and keeping it overnight (Fig. 1). Similarly, the sand with different concentrations of MOCP of 3 (Conc.3), 4 (Conc.4), 5 (Conc.5), 6 (Conc.6), 7 (Conc.7) and 8 (Conc.8) g was prepared.

\section{Characterization studies}

FTIR stands for Fourier transform infrared, in which IR radiation is passed through a sample. Some of the infrared radiation is absorbed by the sample, while other radiation is passed through transmitted. The spectrum obtained represents the molecular absorption and transmission, creating a molecular fingerprint of the sample. The unknown functional groups along with the consistency of the sample can be identified. The amount of material present can be

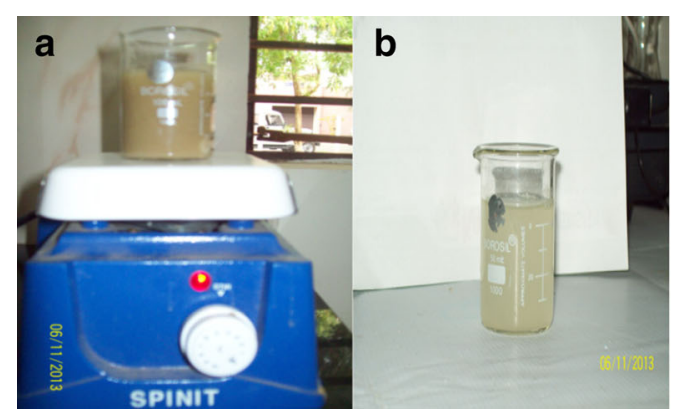

C

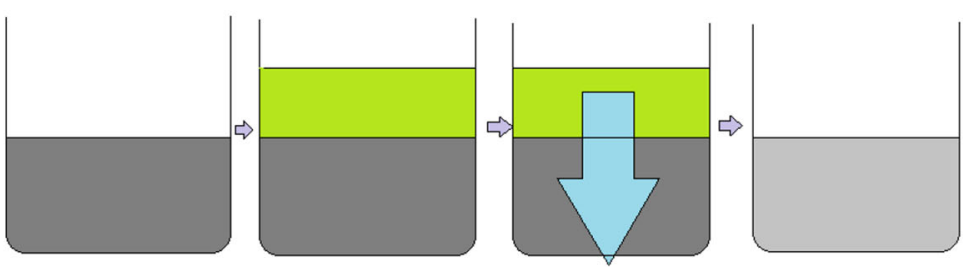

Fig. 1 a Preparation of Moringa extract, b Moringa extract, $\mathbf{c}$ preparation of MOCP c-sand 
identified by the size of the peaks in the resulting spectrum. With modern software algorithms, infrared is an excellent tool for quantitative analysis. The FTIR spectrum was recorded on IR Prestige-21, Shimadzu spectrophotometer at ambient temperature using a $\mathrm{KBr}$ disk method. The disk containing $0.0010 \mathrm{~g}$ of the sample and $0.3000 \mathrm{~g}$ of fine grade $\mathrm{KBr}$ was scanned at 16 scans at wave number range of $400-4000 \mathrm{~cm}^{-1}$. In this study, FTIR analysis was done to observe the changes in the molecular groups in Moringa extract, sand and MOCP c-sand (before and after treatment).

To identify the structure properties like grain size, epitaxy, phase composition and thickness of thin films and multilayers, X-ray diffraction (XRD), a nondestructive technique is used. The study was carried out using JEOL JDX 8030 Model 6000 diffractometer with $\mathrm{Cu}-\mathrm{K}$ radiation $(\lambda=0,15,406 \mathrm{~nm})$ to study the microstructure of the ordinary sand and MOCP c-sand. The diffractogram was scanned in the ranges from $2^{\circ}$ to $10^{\circ}$ at a scan rate of $1^{\circ}$ $\mathrm{min}^{-1}$. The Bragg law was used to explain the interference pattern of X-rays scattered by crystals. The diffraction is developed to measure the average spacing between layers and rows of atoms and determine the orientation of a single crystal or grain. Thus, the crystal structure of an unknown material and measurement of the size, shape and internal stress of small crystalline regions are done using XRD technique.

A scanning electron microscope (SEM) is one of the high-end electron microscopes that produces images of a sample by scanning it with a focused beam of electrons. In this work, the surface morphology studies were carried out by scanning electron microscope (SEM) by JEOL, JSM 35 CF, Japan.

\section{Experimental investigations}

\section{Column experiments}

The synthetic water was prepared by adding $10 \mathrm{~g}$ of calcium chloride and $5 \mathrm{~g}$ of magnesium chloride to 101 of tap water, and the initial concentrations of hardness and chloride were determined. Nano-sized c-sand was prepared by powdering ordinary c-sand using ball miller. A filtration column was made using a container with perforations at the bottom. It was then held upside down, and a filter paper was placed at the bottom of the filter. The column was filled with three layers of MOCP c-sand, each layer being compacted after adding the next layer. One more filtration column was made with ordinary sand alone without Moringa extract. Like this three filter columns were set up with ordinary sand, MOCP c-sand and nano-sized MOCP c-sand each at a height of $10 \mathrm{~cm}$. The synthetic water was allowed

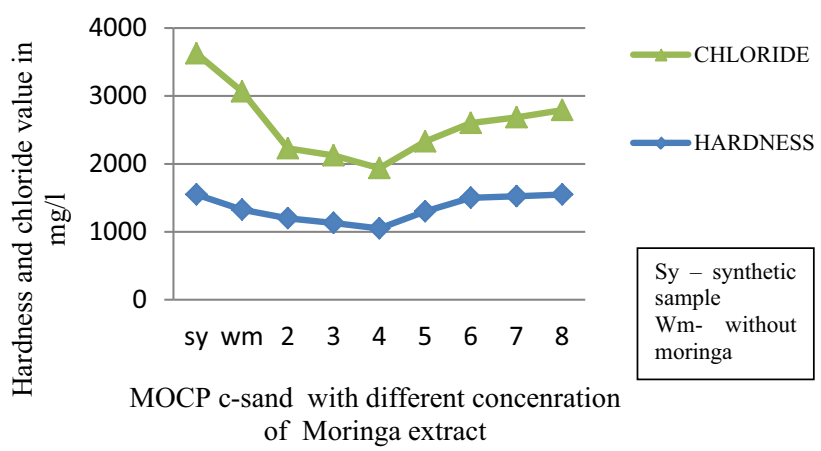

Fig. 2 Removal of hardness and chloride using MOCP c-sand of various concentrations of MOCP

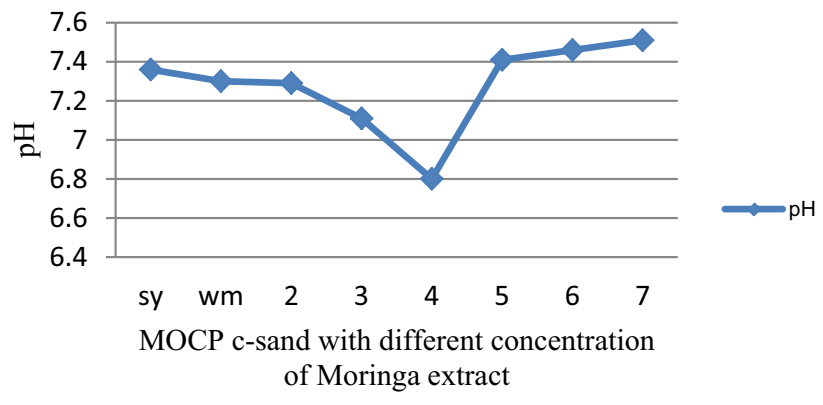

Fig. 3 Observed $\mathrm{pH}$ during column experiments

to pass through the columns at the rate of $5 \mathrm{ml} / \mathrm{min}$, and the water quality parameters such as hardness, chloride, total dissolved solids (TDS), electrical conductivity (EC), $\mathrm{pH}$ and turbidity of the treated water were analyzed using analytical and instrumental techniques in Water Institute, Karunya University. Nine different column experiments were conducted with layers of sand prepared from various concentrations of MOCP mentioned above. The column experiments were conducted for 13 days $(6 \mathrm{~h} /$ day) till the steady state was attained, and the water quality parameters were analyzed at an interval of $1 \mathrm{~h}$. From the results obtained, the optimum quantity of MOCP c-sand required in maximum softening of the water was obtained. The prepared MOCP $\mathrm{c}$-sand was stored for 3 months to evaluate the efficiency of protein in Moringa in treating water.

\section{Results and discussion}

\section{Water quality parameters before and after filtration}

The results of the observed water quality parameters in the column (before and after filtration) are depicted in Figs. 2 and 3. It was observed that the maximum removal of chloride and hardness occurred in the column which was run with MOCP c-sand prepared with $4 \mathrm{~g}$ of Moringa seed 
Table 1 Results of water quality parameters of filtered water using four types of sand layers (MOCP c-sand prepared with $4 \mathrm{~g}$ of Moringa seed powder)

\begin{tabular}{llllll}
\hline No. & Parameters & $\begin{array}{l}\text { Sand without Moringa } \\
\text { extract (reduction \%) }\end{array}$ & $\begin{array}{l}\text { Fresh MOCP c-sand } \\
\text { (reduction \%) }\end{array}$ & $\begin{array}{l}\text { MOCP c-sand stored } \\
\text { for 3 months (\%) }\end{array}$ & $\begin{array}{l}\text { Nano-sized MOCP } \\
\text { c-sand (\%) }\end{array}$ \\
\hline 1 & Hardness (mg/l) & 14 & 32 & 28 & 62 \\
2 & Chloride (mg/l) & 16 & 54 & 51 & 67 \\
3 & EC (mS) & 8 & 47 & 41 & 62 \\
4 & TDS & 16 & 80 & 74 & 89 \\
5 & Turbidity & 20.4 & 98 & 94 & 100 \\
\hline
\end{tabular}

powder as shown in Table 1. It was also perceived that the treated sample becomes alkaline beyond the optimum value of MOCP c-sand (Figs. 2, 3).

The same set of column experiments were carried out using stored MOCP c-sand (for 3 months), and the water quality parameters were analyzed. Also recycled/treated sewage water (containing fecal coliform) taken from sewage treatment plant at Karunya University was also passed through MOCP c-sand of Conc.4, and percentage removal of total coliform and fecal coliform was calculated. The observed results confirmed that the stored MOCP c-sand showed the same efficiency of removal of hardness, chlorides, TDS and turbidity as that of freshly prepared sand as shown in Table 1. This is due to the fact that the characteristics of MOCP in the Moringa extract are preserved when coated over the sand and maintained in dry condition. So the positive charges on the surface of MOCP c-sand remove the hardness causing anions, chloride and turbidity. Also, the efficiency of MOCP c-sand in the removal of fecal coliform from recycled sewage water at optimized concentration was found to be $80 \%$ due to the antibacterial characteristics of Moringa seeds (Table 2). Due to more surface area of nano-sized MOCP c-sand, the removal efficiency is $30 \%$ higher in terms of hardness and 5-15\% higher in terms of chloride and EC.

\section{FTIR analysis}

The molecular groups present on the surface of MOCP csand after passing synthetic sample were analyzed using FTIR to understand the underlying process in the removal of hardness and chlorides from water as shown in Fig. 5. While comparing the FTIR spectral results of sand, Moringa extract and MOCP c-sand, it is clear that there is a physical adsorption of molecular groups from Moringa extract on the surface of sand. The Moringa extract shows the $\mathrm{OH}, \mathrm{NH}$ groups along with the amine and unsaturated acid groups and protein. The acid groups in Moringa reacted with $\mathrm{CaCl}_{2}$, and during the reaction, the Ca remains in the sand and $\mathrm{HCl}$ is formed which got neutralized due to
Table 2 Coliform values of sewage water after filtration through fresh MOCP c-sand prepared with $4 \mathrm{~g}$ of Moringa seed powder

\begin{tabular}{ll}
\hline Water sample & $\begin{array}{l}\text { Fecal coliform } \\
\text { (CFU/100 ml) }\end{array}$ \\
\hline $\begin{array}{l}\text { Treated sewage water from sewage } \\
\text { treatment plant }\end{array}$ & 2400 \\
$\begin{array}{l}\text { Treated sewage water after passing } \\
\text { through MOCP c-sand }\end{array}$ & 240 \\
\hline
\end{tabular}

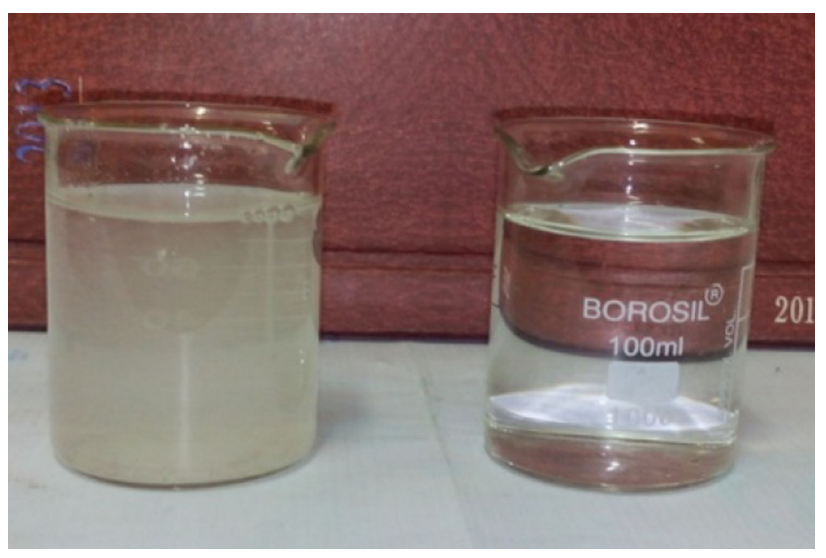

Fig. 4 Synthetic water before and after filtration

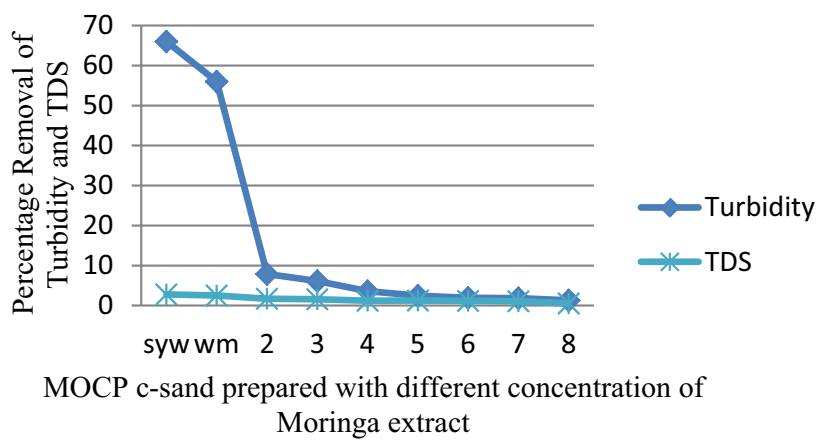

Fig. 5 Removal of TDS and turbidity using c-sand with different concentrations of Moringa powder 

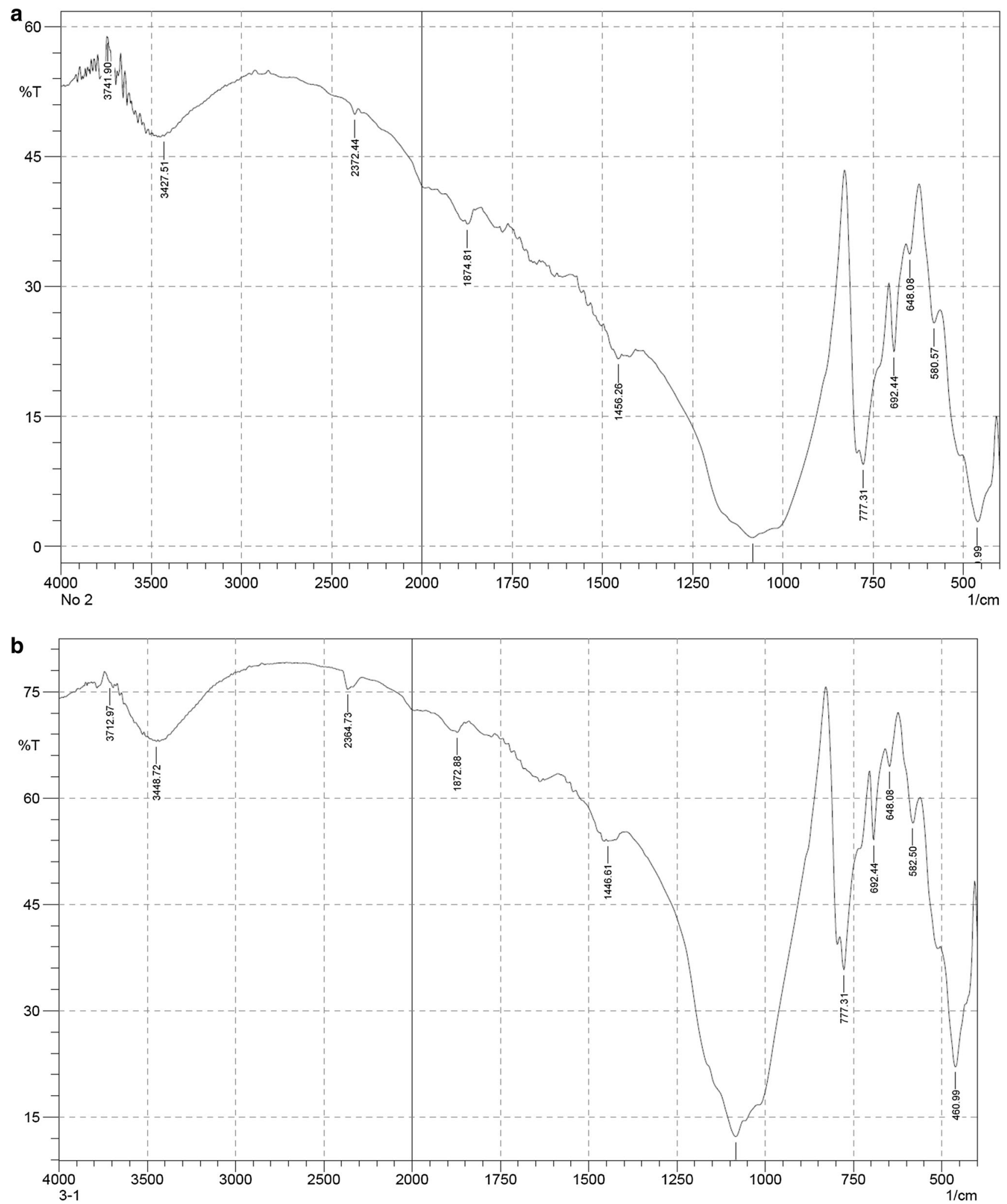

Fig. 6 FTIR spectrum a fresh sand, b MOCP C-sand and c Moringa extract 


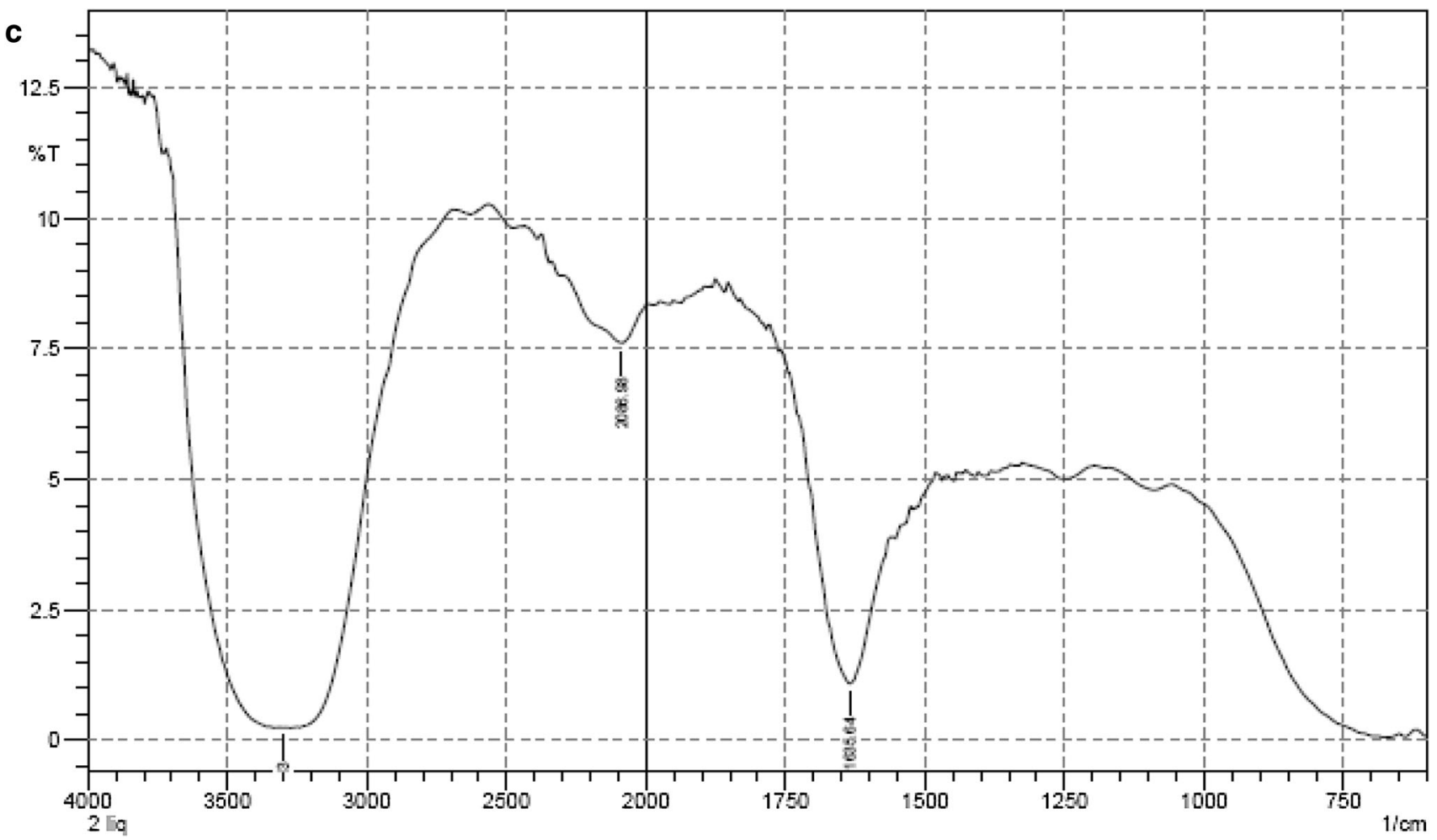

Fig. 6 continued

the amides and also further reduction of chloride took place. This type of reaction might have continued up to Conc.4. After that the process of amine was dominated and the negatively charged particles might have got absorbed by sand which caused a faster rate of turbidity reduction at higher concentration.

$\mathrm{R}-\mathrm{CO}_{2} \mathrm{H}+\mathrm{CaCl}_{2} \rightarrow\left(\mathrm{R}-\mathrm{CO}_{2}\right)_{2} \mathrm{Ca}+\mathrm{HCl}$

The results showed the presence of multiple hydroxyl, lactone and unsaturated ketone groups $(\mathrm{C}=\mathrm{O})$ in Moringa extract at bands of $3427,2372,1874$ and $1,456 \mathrm{~cm}^{-1}$. The bands at $3435,1082,1175,773,692,648,590 \mathrm{~cm}^{-1}$ show the presence of absorbed water, $\mathrm{SiO}$ stretching, $\mathrm{Si}-\mathrm{O}-\mathrm{Si}$ stretching, $\mathrm{Si}-\mathrm{O}$ symmetric stretching, $\mathrm{Si}-\mathrm{O}-\mathrm{Al}$ asymmetric bending, $\mathrm{Si}-\mathrm{O}-\mathrm{Si}$ asymmetric bending in sand. Also there is an evidence of the presence of amide group in Moringa extract at $1635 \mathrm{~cm}^{-1}$ and $\mathrm{N}-\mathrm{H}$ stretching at the band of $3472 \mathrm{~cm}^{-1}$ in fresh MOCP $\mathrm{c}$-sand. The chloride removal up to optimum value was due to replacement of $\mathrm{H}^{+}$ions in $\mathrm{N}-$ $\mathrm{H}$ stretched bond by $\mathrm{Ca}^{2+}$ from $\mathrm{CaCl}_{2}$ and formation of $\mathrm{HCl}$. So $\mathrm{pH}$ is reduced to 6.8 until it reached optimum value (Conc.4). Beyond that optimum value at Conc.4, there is replacement of hydroxyl group by other anions which reduces TDS and turbidity (Fig. 4). This increases $\mathrm{pH}$ of the sample as shown in Fig. 3. The column was run with c-sand prepared with extract of $8 \mathrm{~g}$ of Moringa seeds; it was observed that the reduction in turbidity, TDS and EC was 98, 80 and 47\%, respectively (Fig. 5). This is confirmed by the absence of $\mathrm{N}-\mathrm{H}$ stretching and amide group on the surface of used MOCP c-sand after water purification (Fig. 6).

\section{Microstructure and Surface morphology Analysis}

From the XRD result given in Table 3, average crystallite size can be computed (Fig. 7). It is done by substituting the values of 3 strong peaks from the XRD result in the formula: $d=0.9 \quad \lambda / \beta \cos \theta$, where $\lambda=1.5406 \times 10^{-10} ; \quad \beta=\mathrm{FWHM} / 3 ; \quad d=$ interplanar spacing. The crystallite size of MOCP c-sand sample prepared with $2 \mathrm{~g}$ of Moringa seeds is $67.44 \mathrm{~nm}$, and it gradually got reduced to $44.40 \mathrm{~nm}$ at Conc.7. From that, it is clear that average crystallite size is reduced with the increase in concentration resulting in the reduction of turbidity and TDS.

The surface morphology studies were carried out for ordinary sand and MOCP c-sand of various concentrations after ball milling using SEM, and the results are presented in Table 4 and Fig. 7. Figure 8 shows that sand has irregular and flaky morphology and MOCP is unevenly 


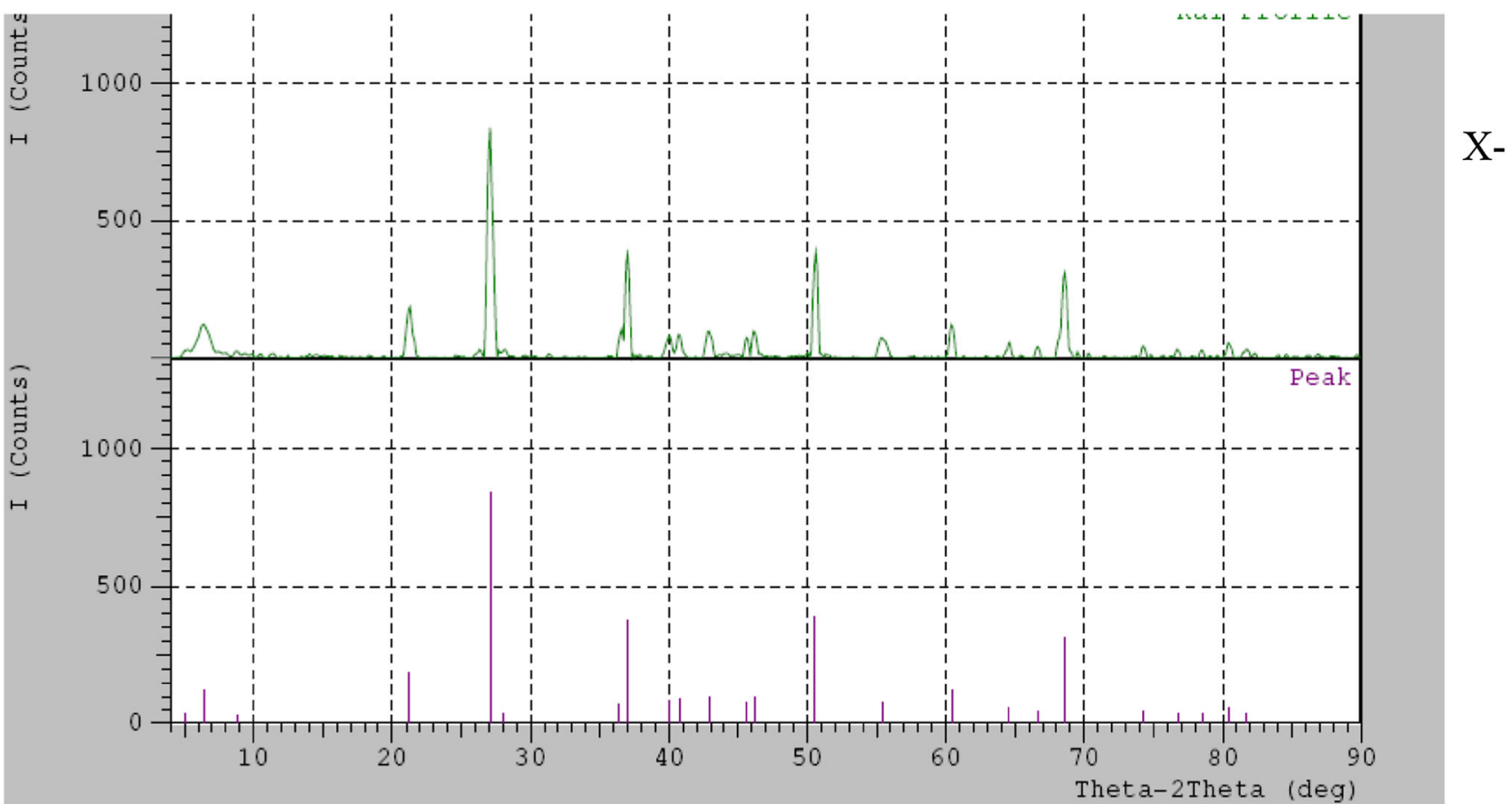

Fig. 7 X-ray diffraction (XRD) of the sample (Conc.4)

Table 3 Microstructure of the coated MOCP on the sand before and after filtration using XRD results

\begin{tabular}{lll}
\hline $\begin{array}{l}\text { Nano-sized } \\
\text { MOCP c-sand }\end{array}$ & $\begin{array}{l}\text { Average crystallite } \\
\text { size }(\mathrm{nm}) \text { before } \\
\text { filtration }\end{array}$ & $\begin{array}{l}\text { Average crystallite } \\
\text { size }(\mathrm{nm}) \text { after } \\
\text { filtration }\end{array}$ \\
\hline $2 \mathrm{~g}$ & 67.44 & 73.37 \\
$3 \mathrm{~g}$ & 61.9 & 65.14 \\
$4 \mathrm{~g}$ & 57.86 & 40.63 \\
$5 \mathrm{~g}$ & 48.76 & 43.55 \\
$6 \mathrm{~g}$ & 49.67 & 51.2 \\
$7 \mathrm{~g}$ & 44.40 & 47.78 \\
Sand without & 70 & 69.11 \\
Moringa & & \\
\hline
\end{tabular}

Table 4 Average particle size range of MOCP coated on the sand before and after filtration based on the SEM results (Fig. 6)

\begin{tabular}{lcc}
\hline $\begin{array}{l}\text { MOCP } \\
\text { c-sand }\end{array}$ & $\begin{array}{l}\text { Average particle } \\
\text { size range }(\mathrm{nm}) \\
\text { before filtration }\end{array}$ & $\begin{array}{l}\text { Average particle } \\
\text { size range }(\mathrm{nm}) \\
\text { after filtration }\end{array}$ \\
\hline $2 \mathrm{~g}$ & $100.00-392.39$ & $130.54-247.39$ \\
$3 \mathrm{~g}$ & $106.64-318.68$ & $128.06-350.00$ \\
$4 \mathrm{~g}$ & $104.35-194.14$ & $200-644.98$ \\
$5 \mathrm{~g}$ & $94.28-261.28$ & $126.49-266.27$ \\
$6 \mathrm{~g}$ & $122.54-243.31$ & $110.00-311.13$ \\
$7 \mathrm{~g}$ & $93.57-257.60$ & $85.44-220.23$ \\
Sand without & $126.49-193.85$ & $106.00-188.65$ \\
$\quad$ Moringa & & \\
\hline
\end{tabular}

distributed on sand. At higher concentration of Moringa extract, the particle size of MOCP is decreased. As particle size is getting decreased, the surface area increases and sand becomes much efficient in removing turbidity and TDS. It was observed through SEM images that the average particle size range of MOCP c-sand coated with $4 \mathrm{~g}$ of Moringa before passing water is least (104.35-194.14 nm) and it becomes maximum when water is passed through the filtration column (200-644.98 nm) as shown in Table 4. The XRD and FTIR results confirm the same. Thus, it is concluded that MOCP c-sand prepared using the extracts from $4 \mathrm{~g}$ of Moringa seed powder showed the optimum result in the removal of hardness, chloride, TDS and turbidity in addition to the removal of total coliform and fecal coliform.

\section{Summary and conclusion}

Moringa alone has been shown to provide many extremely important benefits to the communities where it is grown. Moringa seeds can be used to produce clean and safe drinking water easily, inexpensively and quickly. Finding a way to use Moringa to produce potable water would provide a socially, environmentally and economically sustainable way for a developing community to gain access to potable water. This work has shown that MOCP retains its functionality when adhered to the surface of sand and the problematic excess organic matter is rinsed away. In this 

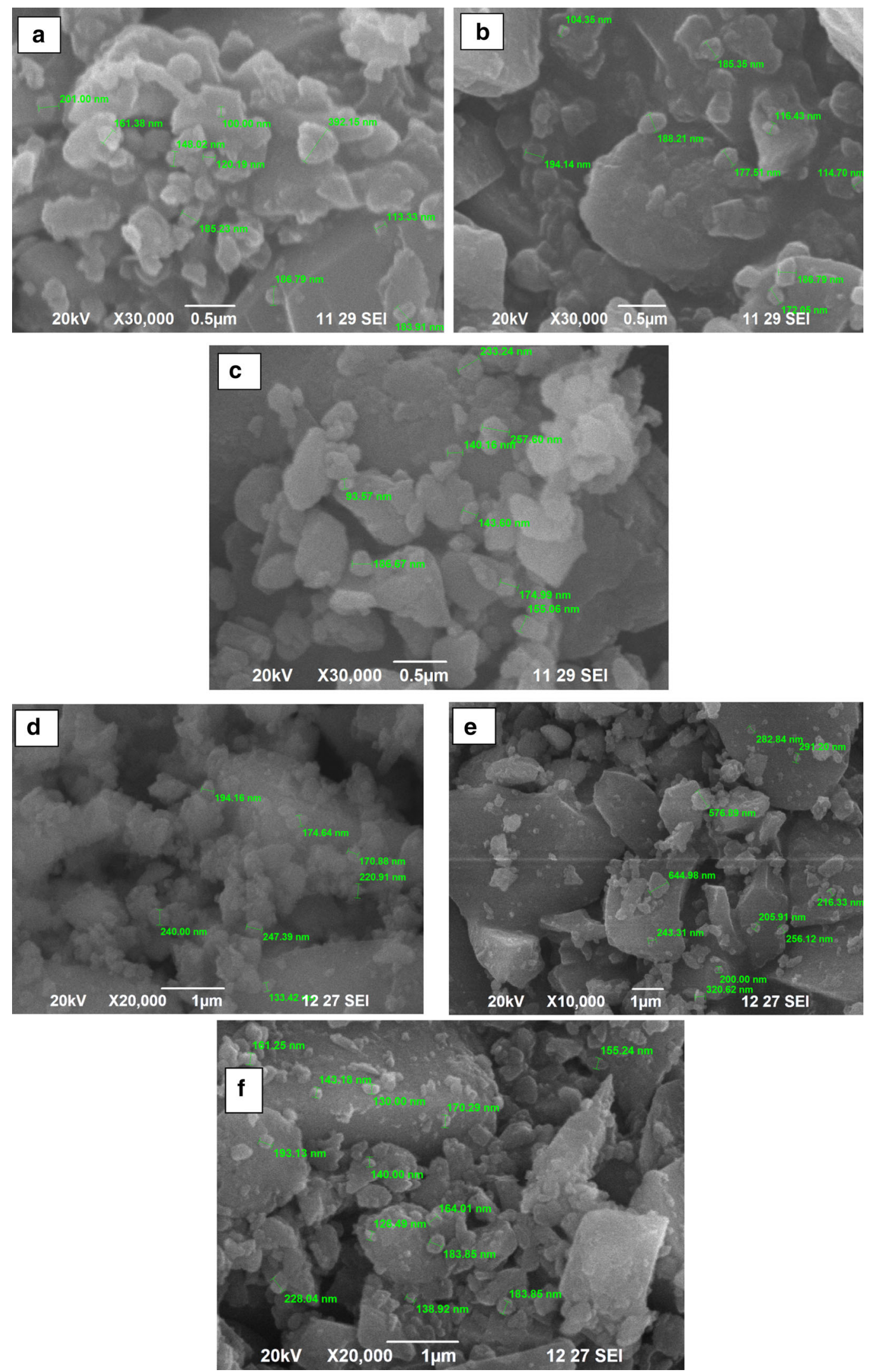

Fig. 8 SEM images of MOCP c-sand prepared with concentration 2, 4, $7 \mathrm{~g}$ of Moringa a-c before passing synthetic water through column and d-f after passing synthetic water 
work, it has been shown that the amount of TH, chloride, TDS can be reduced using MOCP c-sand and turbidity can be fully removed. Additionally, it is convenient to store the MOCP c-sand and used when needed. In this work, it was shown that MOCP c-sand which was stored for 3 months exhibits the same efficiency in the removal of turbidity, TDS and hardness. This is convenient because the MOCP c-sand can be prepared when seeds are available. Storing the MOCP c-sand instead of the unused seeds reduces the risk of loss to animals or bugs. It also allows community members to obtain clean drinking water within an hour even if the store of potable water is used up. The results also show that only $4 \mathrm{~g}$ of M.O seed powder is required to make $300 \mathrm{~g}$ of MOCP c-sand for making a water purifier for removing turbidity, TDS, chloride and hardness which proves that this system is cost-effective in rural and periurban areas.

Open Access This article is distributed under the terms of the Creative Commons Attribution 4.0 International License (http:// creativecommons.org/licenses/by/4.0/), which permits unrestricted use, distribution, and reproduction in any medium, provided you give appropriate credit to the original author(s) and the source, provide a link to the Creative Commons license, and indicate if changes were made.

\section{References}

Alo MN, Anyim C, Elom M (2012) Coagulation and antimicrobial activities of Moringa oleifera seed storage at $3 \mathrm{C}$ temperature in turbid water. Pelagia Res Libr Adv Appl Sci Res 3(2):887-894

Anjorin TS, Ikokoh P, Okolo S (2010) Mineral composition of Moringa oleifera leaves, pods and seeds from two regions in Abuja, Nigeria. Int J Agric Biol 12:431-434

Crapper DR, Krishnan SS, Dalton AJ (1973) Brain aluminum distribution in Alzheimer's disease and experimental neurobrillary degeneration. Science 180:511-513

Dalen MB, Pam JS, Izang A, Ekele R (2009) Synergy between Moringa oleifera seed powder and alum in the purification of domestic water. Sci World J 4(4):1597-6343

Egbuikwem PN, Sangodoyin AY (2013) Coagulation efficacy of Moringa Oleifera seed extract compared to alum for removal of turbidity and E. coli in three different water sources. Eur Int. J Sci Technol 2(7):13-20

Eman NA, Suleyman AM, Hamzah MS, Zahangir A, Ramlan MS (2010) Production of natural coagulant from Moringa oleifera seed for application in treatment of low turbidity water. JWARP 2(3):259

Emelie A, Bergman M, Matsinhe N, Kenneth MP (2008) Assessment of drinking water treatment using Moringa oleifera natural coagulant. Vatten 64:137-150
Fahey JW (2005) Moringa oleifera: A review of the medical evidence for its nutritional, therapeutic, and prophylactic properties. Part 1. Trees Life J 1:5-20

Malusare CN, Milind RG (2011) Study of Moringa oleifera extracts in water treatment. A national seminar vision 2025, technological developments in biological sciences. Patkar-Varde college, Mumbai

Mangale SM, Chonde SG, Raut PD (2012) Use of Moringa oleifera (Drumstick) seed as natural absorbent and an antimicrobial agent for ground water treatment. Res J Recent Sci 1(3):31-40

Mcullough LR (2012) Confirmation of adherence of Moringa oleifera cationic protein to sand and storability of functionalized sand. The Pennsylvania State University Schreyer honors college, Spring

Mumuni A, Oloruntoba MPH, Elizabeth O, Sridhar MKC (2013) Use of Moringa oleifera (lam.) seed powder as a coagulant for purification of water from unprotected sources in Nigeria. Eur Sci J 9(24):1857-7881

Mustapha HB (2013) A review of the applications of Moringa oleifera seeds extract in water treatment. Civil Environ Res 3(8): $1-10$

Muyibi SA (1998) Moringa oleifera seed extract in water treatment. J Inst Eng Malay 59(3):37-50

Muyibi SA, Birima AHB, Mohammed TA, Noor MM (2004) Conventional treatment of surface water using Moringa oleifera seeds extract as a primary coagulant. IIUM Eng J 5(1):1-11

Ndabigengesere A, Narasiah KS, Talbot BG (1995) Active agent and mechanism of coagulation of turbid waters using Moringa oleifera. Water Res 2:703-710

Nilani P, Pinaka MK, Duraisamy B, Dhamodaran P, Jeyaprakash M (2012) Anthelmintic activity of Moringa oleifera seed oil. Validation of traditional use. J Adv Sci Res 3(2):65-66

Nwaiwu NE, Moses J (2010) The performance of Moringa oleifera seed powder sodium chloride extract on natural surface water. Cont J Eng Sci 5(2):55-66

Olayemi AB (1994) Studies on traditional water purification using Moringa oleifera seed. African study monographs 15(3):135-142

Sotheeswaran S, Nand V, Matakite M, Kanayathu K (2011) Moringa oleifera and other local seeds in water purification in developing countries. Res J Chem Environ 15(2):135-138

Stavros L, John T (2002) Characterization of Moringa oleifera seed oil variety, periyakulam. J Food Compos Anal 15:65-77

Suet MH, Wing ST (1992) Sanitary and health aspects of aluminium in drinking water. Water Supply 10:11-20

Vijay KK, Rubha MN, Manivasagan M, Ramesh BNG, Balaji P (2012) Moringa oleifera. The Nature's Gift'. Univ J Environ Res Technol 2(4):203-209

Vinoth B, Manivasaga PR, Balamurugan S (2012) Phytochemical analysis and antibacterial activity of Moringa oleifera lam. Int $\mathbf{J}$ Res Biol Sci 2(3):98-102

Yarahmadi M, Hossieni M, Bina B, Mahmoudian Naimabadie, Shahsavani A (2009) Application of Moringa oleifera seed extract and polyaluminum chloride in water treatment. World Appl Sci J 7(8):962-967 